Article

\title{
Conceptualizing Interactions between SDGs and Urban Sustainability Transformations in Covid-19 Times
}

\author{
Kerstin Krellenberg ${ }^{1,2, *}$ and Florian Koch ${ }^{2,3}$ \\ ${ }^{1}$ Department of Geography and Regional Research, University of Vienna, 1010 Vienna, Austria; \\ E-Mail: kerstin.krellenberg@univie.ac.at \\ 2 Department of Urban and Environmental Sociology, Helmholtz Centre for Environmental Research, 04318 Leipzig, \\ Germany \\ ${ }^{3}$ Department of Economics and Law, University of Applied Sciences, 10318 Berlin, Germany; \\ E-Mail: florian.koch@htw-berlin.de \\ * Corresponding author
}

Submitted: 26 August 2020 | Accepted: 11 December 2020 | Published: 26 February 2021

\begin{abstract}
Given the potential of cities to contribute to a more sustainable world as framed by the Sustainable Development Goals (SDGs) of the UN 2030 Development Agenda, this article focuses on Urban Sustainability Transformations. We take a closer look at the potentials, contradictions and challenges that SDG implementation in cities involves in light of the current Covid-19 pandemic. We argue that SDG implementation needs to consider these global challenges in order to pursue its transformative approach. As a starting point we take SDG 11 and its subtargets to achieve resilient cities and communities, with a focus on German cities. The article will thus contribute to the discussion on the constraints associated with implementing SDGs in cities, given the multiple challenges and actors involved, and the complexity this implies for Urban Sustainability Transformations.
\end{abstract}

\section{Keywords}

cities; Covid-19; Germany; pandemic; SDGs; urban sustainability

\section{Issue}

This article is part of the issue "The 2030 Agenda for Sustainable Development: Transformative Change through Sustainable Development Goals?" edited by Thomas Hickmann (University of Utrecht, The Netherlands), Markus Lederer (Technical University of Darmstadt, Germany), Jens Marquardt (Technical University of Darmstadt, Germany), Sandra Schwindenhammer (Justus Liebig University Giessen, Germany) and Sabine Weiland (Catholic University of Lille, France).

(C) 2021 by the authors; licensee Cogitatio (Lisbon, Portugal). This article is licensed under a Creative Commons Attribution 4.0 International License (CC BY).

\section{Introduction: The Urban Dimension of Transformations to Sustainability}

Ongoing debates on sustainability highlight the need for far-reaching radical processes of change, since piecemeal changes of current modes of development seem to lack the wherewithal to achieve a more sustainable world (Brand, 2016). These changes, so-called transformations to sustainability (Hackmann \& Lera St. Clair, 2012), are coveted in a variety of sectors, such as agriculture, industrial production and consumption.
Urban areas are another prominent sphere with a clearly visible need for transformations to sustainability. Current forms of urban development have been proved widely unsustainable (Loorbach \& Shiroyama, 2016) and cannot be interpolated in the future, as planetary boundaries are soon expected to be crossed. We argue, like other authors (e.g., German Advisory Council on Global Change, 2011; McCormick, Anderberg, Coenen, \& Neij, 2013), that transformation towards more sustainable development is necessary if cities are to contribute to managing the consequences of Global Environmental 
Change, as well as of demographic and economic change. This not least because the heavy use of resources contributes substantially to Global Environmental Change, notably as a result of high greenhouse gas emissions.

In this context, we consider Urban Sustainability Transformations as radical, multi-dimensional alterations to a given system that can go across system borders and deal with multiple as well as uncertain development options (McCormick et al., 2013). As a planned solution towards sustainable development in cities, Urban Sustainability Transformations should be understood as non-linear expressions of complex interactions and consequences of a wide range of different processes.

The 'Global Sustainable Development Report 2019: The Future is Now' sees urban and peri-urban development as one of the six entry points that "offer the most promise for achieving the desired transformations at the necessary scale and speed" (Messerli et al., 2019, p. XXI). Since the majority of humankind lives in urban and peri-urban areas (and this share is likely to increase by 2050), urban sustainability plays a major role in achieving the 2030 Agenda. While the important role of cities in the global sustainability discourse has gained increased recognition and become a new paradigm for future development (Angelo \& Wachsmuth, 2020), there is less unanimity on the question of how cities should actually be transformed into a more sustainable version of themselves.

The 2030 Agenda and its Sustainable Development Goals (SDGs) pursue a transformative programme, as its full title 'Transforming our world' demonstrates. The shift towards an urban dimension to political sustainable agendas is notably reflected in SDG 11 "making cities and human settlements inclusive, safe, resilient and sustainable" (UN, 2015). Other SDGs, such as 4, 6 and 13 , also make strong reference to urban areas as an arena for their implementation and demonstrate that Urban Sustainability Transformations should address different sectors. Furthermore, the UNs' New Urban Agenda, which was adopted at the Habitat III conference in Quito in 2016, sets standards and principles for local SDG implementation. It aims to provide the groundwork for urban policies and approaches towards a more sustainable urban development (UN Habitat, 2015). The mixed outcomes of the Habitat III conference and complaints about a lack of binding global and national agreements again demonstrate that implementing urban development calls for transformation to more sustainable situations than currently prevail. Although the New Urban Agenda points out opportunities for urbanization as an engine of sustainability (UN, 2015), how these radical transformations as indicated by the SDGs are to be achieved remains vague. SDG 17 presents initial ideas on implementing Urban Sustainability Transformations on a global scale. Among these are capacity development, finance, and systemic issues (UN, 2015). It is, nonetheless, more a general guideline than a concrete manual.
Quite a number of articles have been published in response to the adoption of SDGs in cities, pointing out a range of difficulties (see, for example, Fenton \& Gustafsson, 2017; Koch et al., 2019; Krellenberg, Koch, Schubert, \& Libbe, 2019; Patel et al., 2017; Simon et al., 2016), and highlighting the need for appropriate indicators, existing SDG data problems, governance issues, and lack of financial resources. One key aspect is the level of concreteness. We argue that support for the implementation of SDGs in cities calls for a stronger focus on specific urban characteristics, processes, and targets in the context of shifting towards sustainability. This corresponds to what has been established in the context of other related terms and concepts, such as urban vulnerability (Krellenberg, Welz, Link, \& Barth, 2016; Romero-Lankao \& Qin, 2011) or urban resilience (Meerow, Newell, \& Stults, 2016): Urban issues has become a buzz word without the necessary emphasis on specific 'urban' aspects that make a difference. According to Krellenberg et al. (2016) we see cities as a social product, characterized by a concentration of physical assets such as housing, infrastructure and communication networks, as an engine of economic growth, as centres of political power and representation, with consumers of ecological resources and producers of contaminants, hubs of cultural diversity and resource, as well as the outcome of the historical aggregation of physical assets. Following the distinction made by McCormick et al. (2013, p. 4), that "sustainable urban development is primarily about development in urban areas while sustainable urban transformation is about development or change of urban areas," it is precisely this embedment of the SDGs for urban transformations in an overall sustainable urban development framework that we argue is still missing. Furthermore, we contend that SDG implementation in cities must also take account of current global challenges and developments in order to pursue its transformative approach.

Since the adoption of the 2030 Agenda in 2015, profound societal and technological changes have taken place, but are not yet reflected in the SDGs. The most radical game changer has been the Covid-19 pandemic and its global impact on the economy and society at large. The question arises as to whether Covid-19 necessitates a realignment of the SDGs and their respective targets and indicators. Initiatives such as the 'Make sustainability a top priority to bolster resilience!' by the German Science Platform Sustainability 2030 has underlined the relationship between sustainability transformations and SDGs, arguing that post-pandemic economic recovery should follow SDG guidelines. Following this up, the UN High Level Political Forum points out that "the Covid-19 pandemic has highlighted the important role of local governments as the provider of services closest to people" (High Level Political Forum on Sustainable Development, 2020).

While several articles have been published on how Covid-19 possibly affects the way in which cities are organized (Megahed \& Ghoneim, 2020; Sharifi \& 
Khavarian-Garmsir, 2020; Venter, Barton, Gundersen, Figari, \& Nowell, 2020) and why cities are a catalyst for the rapid spread of diseases such as Covid-19 (Neiderud, 2015), the impact of Covid-19 on the urban implementation of SDGs remains fuzzy. This is reflected, for example, in the UNESCO argumentation that the severe impact of the Covid-19 pandemic on cities raises fundamental questions about sustainable urban development, and indicates the need to rethink development strategies towards more resource efficiency, quality of life and resilience (UNESCO, 2020). That said, the situation brought about by Covid-19 asks what urban transformations to sustainability should look like and calls for rethinking how cities can contribute to SDG implementation.

In this article we take SDG 11 and its subtargets to achieve resilient cities and communities as a starting point and discuss how the Covid-19 pandemic affects SDG implementation. Here we refer for the most part to the situation in German cities but the findings also stem from and are transferable to cities in other countries. Given the fact that very few research results on the specific impact of Covid-19 on selected fields of sustainability exist, we mainly use recent study reports, working papers and national newspaper articles as sources in describing the specific situation in Germany.

\section{Resilience as a Key Dimension of Urban Sustainability Transformations and the Covid-19 Pandemic}

Cities are places where interwoven processes of Global Environmental Change, demographic and economic change take place simultaneously, with urbanization processes putting continuous pressure on natural resources. In the following, we refer to work that sees the need for urban transformations to sustainability to consider resource efficiency, quality of life and resilience among its key dimensions, such as that of Kabisch et al. (2018), Krellenberg et al. (2016), and Kabisch and Kuhlicke (2014).

Conspicuous in the cities of today is the high exploitation of scarce resources such as land, water and energy. This frequently goes hand in hand with growing social inequality in terms of resource distribution and accessibility and demands new forms of resource efficiency. Resource efficiency is considered a starting point for debates on additional strategies such as resource consistency and sufficiency (Kabisch et al., 2018). Furthermore, local residents aspire to a higher quality of life both for themselves and for future generations, one that points to the benefits of urban transformations, which in turn need to be addressed and communicated in sustainability transformations. These aspects pertain to the physical, social, environmental, economic, and institutional features concerned (Węziak-Białowolska, 2016). In addition, different coping capacity levels of institutions, citizens, and infrastructures with regard to crises or hazardous events should be strengthened in cities, whereby coping capacity refers to the ability to prepare for, cope with and recover from a hazardous event towards resilience. After Meerow et al. (2016, p. 39) "urban resilience refers to the ability of an urban system...to maintain or rapidly return to desired functions in the face of a disturbance, to adapt to change, and to quickly transform systems that limit current or future adaptive capacity." Such actions are designed to allow for a swift return to a state of normality, without implying long-term changes (transformations; Twigg et al., 2017) or adaptation to the hazard concerned (Krellenberg et al., 2016). In our understanding, resilience and transformation are not opposing but complementary concepts, whereas resilience at the end of a transformation process is key to developing long-term dynamic stability (Folke et al., 2011). Although Meerow et al. (2016, p. 46) show that "growing emphasis on enhancing the resilience of cities in the face of unprecedented urbanization and climate change" exists, climate change is by no means the only challenge.

Given the current Covid-19 pandemic, it has perhaps become more obvious than ever before just how vital the resilience dimension is for cities and the degree to which resilience is entwined with resource efficiency and quality of life. Today's supply chains, for example, depend on interregional and international connectivity. The provision of cities with consumer goods hinges on the freeflowing movement of people and goods. In the case of disturbances, however, supply chains may become unstable and jeopardize urban resilience. The Covid-19 situation has proved how vulnerable we are when it comes to a grave crisis, and how this can be a threat to our high dependency on interconnected markets and supply chains. Although the issue of sustainable consumption has evolved on the international policy agenda since the Rio Conference (Cohen, 2020), we were made painfully aware of the implications for our daily lives in the course of worldwide lockdowns. We argue that this indicates the need to adjust current growth-driven strategies and refocus on regional and local production and consumption patterns in order to become more resilient and in turn more sustainable (see also Hakovirta \& Denuwara, 2020). These ideas are far from new but have been discussed for years. This ties in with approaches such as urban metabolism (e.g., Ferrão \& Fernández, 2013; Troy, 2012), circular economies (e.g., Geissdoerfer, Savaget, Bocken, \& Hultink, 2017; Ghisellini, Cialani, \& Ulgiati, 2016), the food-water-energy nexus (RomeroLankao, McPhearson, \& Davidson, 2017), or prosumers (Tukiainen, Leminen, \& Westerlund, 2015), all of which address first and foremost the resource efficiency dimension, albeit with the potential to increase resilience and quality of life in the long run. In the same vein, Bai, Nagendra, Shi, and Liu (2020) argue that during the pandemic people's interest in urban agriculture, for example, increased, yet another method of enhancing resilience.

The pandemic furthermore demonstrates the important role of urban green spaces, for example, and their 
potential to trigger the resilience people need to bounce back to its threats and to contribute to a higher quality of life. Venter et al. (2020) have shown for Oslo that the recreational use of green space in residential areas, city parks and peri-urban areas has increased. Kleinschroth and Kowarik (2020) argue that further development of urban green infrastructure should be an integral part of key changes in response to the experience of the current crisis. That said, it should be kept in mind that urban greening is not socially just per se, and trade-offs between ecological and social outcomes of urban greening strategies do exist and are in greater evidence in pandemic times such as unequal access and distribution (Haase et al., 2017). What is more, urban inequality and inclusive recovery issues are crucial in terms of the link between sustainability and pandemic response (Acuto, Dickey, Butcher, \& Washbourne, 2020). Overall, Ratho and Johns (2020) concluded for the current global pandemic that cities have so far coped with the situation in different ways, arguing with data from the relevant authorities and their various levels of coordination.

Recent debates in Germany at all levels have addressed resilience in relation to Covid-19 and discussed methods of overcoming the multiple economic crisis caused by the pandemic. It is widely accepted that public funding and policies are needed in order to balance its adverse effects. The state subsidises branches of the economy that have been hardest hit by the crisis, giving companies the chance to bounce back. In this sense, public action against Covid-19 is at first glance a prime example of resilience, because the measures involved serve the rapid "return to desired functions in the face of a disturbance" (Meerow et al., 2016, p. 39). Here, Covid-19 is the disturbance and measures implemented by Germany such as short-time work compensation ('Kurzarbeitergeld') or public funding for the tourism industry evidence attempts to set the scene for a rapid return to the pre-Covid-19 situation. This economic perspective, it should be remarked, does not answer the question of whether a return to the pre-Covid-19 situation is in fact desirable or not, or if windows of opportunity in which to rethink the former status quo in terms of sustainability are envisaged.

We argue that from a sustainability perspective further issues need to be considered: Resilience is taken up in SDG 13 'Climate action,' with resilience understood as the target of strengthening a system against turbulences and creating functions and structures that are less vulnerable in times of crisis (Revi et al., 2014). This relates to the conviction that sustainable development can only be achieved with effective climate action, such as mitigation and adaptation. Target 13.1 of this SDG reads as follows: 'Strengthen resilience and adaptive capacity to climate-related hazards and natural disasters in all countries.' In other words, the aim is to achieve transformation towards $\mathrm{CO}_{2}$ neutrality in cities-undoubtedly a tremendous contribution to climate change mitigation und sustainability-since resource efficiency alone would not produce the necessary input. Instead, measures should also comprise environmental and ecological issues other than energy, such as water, biodiversity, and natural resources (de Jong, Joss, Schraven, Zhan, \& Weijnen, 2015). In this light, "providing equally distributed ecosystem services and guaranteeing positive community perception and involvement in the management of these services is what builds the basis for future sustainable and resilient cities" (Chelleri, Kua, Sanchez, Nahiduzzaman, \& Thondhlana, 2016, p. 5), which likewise ties in with SDG interlinkages. Coming back to the example of urban green spaces, these bear the potential to reduce, for example, urban flooding events as well as urban heat islands (Koch, Bilke, Helbig, \& Schlink, 2018). In short, current Covid-19 resilience strategies need to address a broader sustainability context and at the same time take into account the specific situation of each city and the potential contribution of the Covid-19 recovery to Urban Sustainability Transformations.

\section{Building Urban Resilience in Times of Covid-19: Reconsidering SDG 11}

The Covid-19 pandemic clearly reveals how aspects of Urban Sustainability Transformations can change under shifting framing conditions. The pandemic underlines the pressing need for urgent action in terms of, for example, trade and employment, social and public health, and the environment, all of which could endanger SDG implementation (Leal Filho, Brandli, Lange Salvia, RaymanBacchus, \& Platje, 2020). On the other hand, the pandemic also shows us the capacity of people to adapt to change (e.g., home schooling and home office, travel restrictions). It nevertheless remains to be seen how willing people will ultimately be to change their attitudes in the long run, particularly when the restrictions lead to waivers that are unacceptable to some.

Some changes wrought by the pandemic, such as the reduction in car traffic, were seen by many as the few positive effects of Covid-19. As a result of less car traffic, air quality and perceived road safety increased and translated to an increase in the quality of life (NASA, 2020, as cited in Honey-Rosés et al., 2020). This was initially evident with the collapse of the international markets during the pandemic and led to remarkable reductions in mobility and transportation. The effects on air quality were noticeable, indicating a possible positive impact on climate in the long run if this trend were to continue after the pandemic. Telecommunication took the place of meetings face to face and local areas such as nearby green spaces were heavily frequented (Newman, 2020). At the same time, recommended stay at home measures, social distancing practices and the general uncertainty about the course of the pandemic and all that that entails led to much psychological distress and to symptoms of anxiety and depression (Xiong et al., 2020) with a heavy impact on well-being and the quality of life. Hence the 
assumption that the pandemic is a driver of sustainability transformations in cities falls short of reality. In the following, we use the example of SDG 11 to detail postulations emerging from the Covid-19 pandemic and their interaction with SDG 11.

As a point of departure, we argue that the current pandemic not only challenges the way we live in cities but also how our cities are built. Office space could lose in significance as the notion of home office gains currency and buildings need to be multifunctional and more flexible for different uses and users. The consequences for urban structures and the urban-rural relationship are not yet foreseeable in total. City structures could be transformed, however, using alternative design principles. This could lead to positive assumptions about the Covid-19 impact on urban sustainability, such as those of Pinheiro and Luís (2020, p. 2): This "coronavirus-induced pause represents 'a big chance!' for developing more sustainable systems" (see also Sofo \& Sofo, 2020). Cheval et al. (2020) argued in the same vein, stating that the impact of the Covid-19 pandemic may lead to a more sustainable future, including the enhanced resilience of socio-ecological systems and shorter supply chains. In the light of SDG 11, on the other hand, Covid-19 could also lead to developments that are at odds with the targets.

One SDG 11 target reads: 'By 2030, enhance inclusive and sustainable urbanization and capacity for participatory, integrated and sustainable human settlement planning and management in all countries' (Target 11.3). A UN indicator to measure Target 11.3 is 11.3 .1 , 'Ratio of land consumption rate to population growth rate.' It is included in countless local initiatives for SDG implementation and calls attention to an essential principle: to reduce land consumption and use existing land in a more resource efficient way. It also relates to recent discussions on urban development and the strategy to implement compact cities and increase their density. This strategy, which was taken up by the 2030 Agenda, is a fairly recent urban development paradigm, particularly in cities of the Global North. The German Sustainability Strategy gives prominence, for example, to reducing daily land use and set a 30 hectares target (daily land use for new settlements and infrastructure is confined to a maximum of 30 hectares). The desired aim has not yet been achieved, with the daily use of new land totalling 56 hectares (Statistisches Bundesamt, 2020). Nevertheless, there is consensus that a reduction in land consumption is imperative to SDG implementation and the achievement of more sustainable urban development. The focus on more compact cities also contradicts older notions of urban development. These were shaped especially in cities of the Global North by suburbanization tendencies and an ever-increasing land consumption rate (Hamel \& Keil, 2015). Apart from the SDGs, documents such as the New Urban Agenda, the European Urban Agenda and the New Leipzig Charter for urban development likewise mention dense urban structures as a core element of urban sustainability.
During the Covid-19 pandemic, however, this paradigm has been challenged. Recent health recommendations consider social distancing a crucial measure to reduce the spread of Covid-19. Social distancing, i.e., maintaining distance to other people, is an effective way of avoiding further infections and, with additional measures such as wearing masks and regular handwashing, are part of the German strategy to fight Covid-19. While social distancing is vital to reducing Covid-19 infections, its implementation is taxing, particularly in the urban context with dense urban structures, where social distancing is not always feasible. The threshold of a 1.5 metre minimum distance to other people is easier to achieve in rural than in urban communities. At the same time, being out in the fresh air is key to the quality of life and personal wellbeing. It is not surprising, therefore, that Covid-19 has led to a growing demand for private (green) space in cities and large housing estates, as reports from German Real Estate companies demonstrate (Papon, 2020; Pawlik, 2020). In addition, prices for single family housing or row houses with gardens in suburban areas have risen disproportionately since the beginning of the pandemic (Feld, Schulten, Gerling, Simons, \& Wandzik, 2020). Home office activities and the availability of private green spaces were instrumental in this shift in the market. Schneider (2020) argues in an article published by the German Institute for Urban Studies that rural areas and their greater amount of private green spaces could also gain currency as residential locations in post-Covid-19 times. Although it is too early to judge whether this development will continue post-Covid-19, it is at variance with the aim of SDG 11 and the New Urban Agenda to foster denser structures, as well as with former population trends such as 'reurbanization' (Dembski et al., 2019). A widespread argument emerged during the pandemic and sees more private space and less dense structures as boosting the resilience of the city and of society in general, despite early findings on density and Covid-19 in the USA, which revealed that "density is not linked to rates of Covid-19 infection" (Hamidi, Sabouri, \& Ewing, 2020, p. 506; see also Sharifi \& Khavarian-Garmsir, 2020).

Does this mean we should revisit SDG 11 and its target of land consumption reduction? Does Covid-19 call for the comeback of suburbanization because it involves settlement structures that facilitate social distancing? We argue that taking this path would put SDG implementation at risk. While there is no evidence to corroborate that a specific type of built environment helps to reduce the spread of Covid-19, an overhasty comeback of suburbanization would lead to long-term unsustainable forms of settlement structure, since 1) only affluent households could practise social distancing via private green spaces, while poorer households would still suffer from lack of space, thus leading in all probability to greater social polarization and inequality in cities; 2 ) the long-term effects of suburbanization, such as the need for new infrastructure and negative effects on the micro 
climate, are costly; and 3) establishing new, less dense settlement structures that reflect the social distancing concept would generate new path dependencies and be irreversible post-Covid-19.

We argue, therefore, that rapid elimination of the compact city model and the SDG Target 11.3 constitutes a threat, both from an ecological and a socioeconomic perspective. Returning to the idea of urban transformations as radical, multi-dimensional alterations of a given system that can go across system borders and deal with multiple as well as uncertain development options (McCormick et al., 2013), we consider other solutions more appropriate to achieving resilience in a multi-perspective way, simultaneously fighting the pandemic and adhering to the SDGs. Solutions should strive for a more efficient use of the existing urban space, enabling a wide section of the population to practise social distancing. Making public spaces in cities more eligible by enhancing their physical appearance and designing new ideas for their use would heighten the quality of life both during and after the pandemic. A variety of initiatives in cities have reopened spaces originally used for cars for pedestrians and cyclists (Honey-Rosés et al., 2020). Long-term transformations could be achieved, for example, by remodelling underused parking spaces and converting them into multipurpose spaces (Stadtlücken, 2020).

Another target of SDG 11, Target 11.2, reads 'by 2030, provide access to safe, affordable, accessible and sustainable transport systems for all, improving road safety, notably by expanding public transport, with special attention to the needs of those in vulnerable situations, women, children, persons with disabilities and older persons' and also qualifies as a basis for the discussion on Covid-19 resilience strategies. Indicator 11.2.1. 'proportion of population that has convenient access to public transport, by sex, age and persons with disabilities' sheds light on the unbalanced situation in public transport common to cities. Public transport can only be efficient if used by the many. Hence in terms of social distancing requirements to avoid the further spread of Covid-19, people are currently encouraged to avoid public transport because social distancing there is difficult to maintain (Lai, Webster, Kumari, \& Sarkar, 2020). This has led to a decline in the number of public transport passengers (e.g., Kanda \& Kivimaa, 2020; for Germany, see Klein, Köhler, \& Stein, 2020). In German cities, particularly households with higher incomes tend to avoid public transport during the pandemic (Spiegel Mobilität, 2020). The challenge for public transport operators during this time is therefore to provide safe and reliable public transport services (Gutiérrez, Miravet, \& Domènech, 2020). Ideas on how to achieve this in the long run include digitalisation measures such as sensor-based information on train occupancy (Federal Ministry of Transport and Digital Infrastructure, 2020). As an immediate reaction to the Covid-19 pandemic, however, a number of public transport companies reduced the frequency of their bus- es and light rail trains in response to the lower demand (Lill, 2020). This in turn meant that more people crowded into less trains and buses. Almost as a chain reaction, users became disillusioned with packed buses and trains, and reverted to alternative modes of transport, which frequently meant cars but increasingly trips on foot or by bike (Bauer, Bracher, \& Gies, 2020). Cities that had in pre-Covid-19 times endeavoured to foster public transport and reduce individual car traffic encountered a formidable situation. Running public transport efficiently during the pandemic is not an easy task due to the decline in passenger numbers and is seen by passengers as risky. Besides promoting bike lanes and space for walking, cities should look for solutions to the rise in car traffic. SDG subtarget 11.2 seems to have fallen out of time, and Covid-19 social distancing measures could be understood as a call to refocus on private cars and the construction of car-friendly infrastructure.

We argue that despite the challenges presented by Covid-19, turning away from public transport and Target 11.2 would counteract sustainable urban development and lead to undesirable situations, since 1) land as a scare resource is not available for the extension of motorized private transport, 2) social inequalities would most likely intensify due to uneven access to car ownership, and 3) an exponential increase in cars would produce higher emissions and a decline in air quality rates, in turn impacting on climate change and vulnerability to lung disease in general and Covid-19 in particular (Slater, Masih, \& Dutta, 2020).

The importance of resilience is hidden in plain sight when it comes to urban transformations and the sustainability framework. Public transport systems in many cities currently lack resilience and the ability to absorb shocks such as the Covid-19 pandemic. Cities should therefore focus on creating resilient public transport systems and implementing SDG 11.2 instead of promoting private car traffic. In addition, new technologies invented for car-or bike-sharing, such as mobility-as-a-service (Kanda \& Kivimaa, 2020), could be redesigned to make alternative transport more attractive and regulate access to public and green spaces as a means of satisfying current Covid-19 regulations. In this vein, Lai et al. (2020) argue for post-pandemic urban planning with guidelines for density-specific social distancing in mass transport systems, pedestrian sidewalks, parks, bars and restaurants.

\section{Conclusion: The Challenges of Urban Sustainability Transformations in a Situation of Crisis}

Having shown that global challenges like Covid-19 seem, at first sight, to question SDGs with reference to resilience as one of three key Urban Sustainability Transformations dimensions, we argue for fundamental changes that are robust and guarantee the resilience of cities in the long run. We also demonstrated that a back-to-the-roots approach as a Covid-19 strategy may 
well fall short as it fails to make use of windows of opportunity that have emerged in the throes of the pandemic. Resilience needs to be understood not only as a bounce-back goal but as the future-oriented aim of fundamental Urban Sustainability Transformations. Science can contribute to both aspects with more systemic, scenario-based research that tackles sustainability and resilience as cross-cutting and describes alternative development options. Here, the amount of research on the impact of Covid-19 on sustainable development in cities (and beyond) is rising steadily but it still seems too early to predict the long-term effects. Nonetheless, Covid-19 has taught us lessons on Urban Sustainability Transformations and resilience in a moment of unforeseen crisis, and given us the option of rethinking the future of our cities. It has been clearly shown that resilience does not mean the unconditional return to a pre-pandemic state but instead a discussion on the existing structures to be maintained and the new structures to be designed. Given the research gaps and following up on Chelleri, Waters, Olazabal, and Minucci (2015), we therefore plea for more integrated solutions in cities, which favour, for example, climate change mitigation and adaption and social equity aspects in order to take into account the multiple trade-offs blatantly evident in the pandemic situation. Furthermore, considering resilience in a descriptive rather than normative way might allow for greater attention to equity and justice (Weichselgartner \& Kelman, 2015), and account for the power of projects on the ground for more dynamic change (Nightingale et al., 2020).

At the same time, SDGs and their implementation at urban level flag the importance of an inclusive approach: Leave no one behind. Participative approaches in the Covid-19 era and in the logic of combating a pandemic seem outdated. Strong political leaders implement topdown measures that impact heavily on the daily lives of billions of people. While fighting Covid-19 requires uniform and rapid responses and legitimates authoritative measures, SDGs strive for participation, inclusiveness and a bottom-up approach. We argue that this principle is key to SDG implementation in cities and should not be neglected in pandemic times. Research can contribute by analysing windows of opportunity with inclusive approaches, and by means of transdisciplinarity, codesign and co-production, and thus support cities in steering participatory processes.

A robust approach to Urban Sustainability Transformations must also tackle the tension between universal solutions for sustainable urban development and the context-sensitivity of individual cities. Challenges arise in handling the overall aims of the transformative approach of the 2030 Agenda and its SDGs, on the one hand, and the varying institutional, geographic, demographic and economic contexts of each city, on the other. This recognizes that although transformations towards more resilience in different cities call for different forms and different objectives, the underlying principles of
Urban Sustainability Transformations exist and, irrespective of their context, must be applied. In other words, while individual cities may implement diverse initiatives such as 'smart cities,' 'low carbon cities,' 'inclusive cities' or 'healthy cities,' all of which can be considered as singular pathways to sustainable urban development, they do not translate to greater overall resilience. In consequence, the existing context can become a delimiting factor for transformation processes or even be subject to change during the transformation process, as the current Covid-19 pandemic shows. This calls for research that reflects the empirical and comparative perspectives of cities in the light of universal SDGs. More specifically, we see an opportunity to strengthen these SDGs with empirical research on the challenges that cities face in Covid-19 times.

While the idea that cities have the potential to solve our global environmental problems in terms of sustainability is enticing, research has not yet delivered sufficiently on how cities can fulfil this mission. Hence, more theoretical and empirical evidence-based and applied research is needed if we are to provide recommendations for urban transformations dedicated to sustainable development options. In this sense, we support the idea of a globally oriented 'urbanization science' (Solecki, Seto, \& Marcotullio, 2013) and endorse the notion of an 'urban lens' (Acuto, Larcom, et al., 2020), acknowledging that cities can be effective catalysts for sustainable development while at the same time recognizing obstacles and unforeseen global developments such as the Covid-19 pandemic.

\section{Conflict of Interests}

The authors declare no conflict of interests.

\section{References}

Acuto, M., Dickey, A., Butcher, S., \& Washbourne, C.-L. (2020). Mobilising urban knowledge in an infodemic: Urban observatories, sustainable development and the Covid-19 crisis. World Development. Advance online publication. https://doi.org/ 10.1016/j.worlddev.2020.105295

Acuto, M., Larcom, S., Keil, R., Ghojeh, M., Lindsay, T., Camponeschi, C., \& Parnell, S. (2020). Seeing Covid-19 through an urban lens. Nature Sustainability. https://doi.org/10.1038/s41893-020-00620-3

Angelo, H., \& Wachsmuth, D. (2020). Why does everyone think cities can save the planet? Urban Studies, 57(11), 2201-2221.

Bai, X., Nagendra, H., Shi, P., \& Liu, H. (2020). Cities: Build networks and share plans to emerge stronger from Covid-19. Nature, 584(7822), 517-520.

Bauer, U., Bracher, T., \& Gies, J. (2020). Ein anderer Stadtverkehr ist möglich: Neue Chancen für eine krisenfeste und klimagerechte Mobilität [A different kind of urban transport is possible: New opportuni- 
ties for a crisis-proofed and climate-friendly mobility]. Berlin: Agora Verkehrswende.

Brand, U. (2016). "Transformation" as a new critical orthodoxy: The strategic use of the term "transformation" does not prevent multiple crises. GAIAEcological Perspectives for Science and Society, 25(1), 23-27.

Chelleri, L., Kua, H. W., Sanchez, J. P. R., Nahiduzzaman, K. M., \& Thondhlana, G. (2016). Are people responsive to a more sustainable, decentralized, and userdriven management of urban metabolism? Sustainability, 8(3). https://doi.org/10.3390/su8030275

Chelleri, L., Waters, J. J., Olazabal, M., \& Minucci, G. (2015). Resilience trade-offs: Addressing multiple scales and temporal aspects of urban resilience. Environment and Urbanization, 27(1), 181-198.

Cheval, S., Mihai Adamescu, C., Georgiadis, T., Herrnegger, M., Piticar, A., \& Legates, D. R. (2020). Observed and potential impacts of the Covid-19 pandemic on the environment. International Journal of Environmental Research and Public Health, 17(11). https:// doi.org/10.3390/ijerph17114140

Cohen, M. J. (2020). Does the Covid-19 outbreak mark the onset of a sustainable consumption transition? Sustainability: Science, Practice and Policy, 16(1), 1-3.

de Jong, M., Joss, S., Schraven, D., Zhan, C., \& Weijnen, M. (2015). Sustainable-smart-resilient-low carbon-ecoknowledge cities: Making sense of a multitude of concepts promoting sustainable urbanization. Journal of Cleaner Production, 109, 25-38.

Dembski, S., Sykes, O., Couch, C., Desjardins, X., Evers, D., Osterhage, F., . . . \& Zimmermann, K. (2019). Reurbanisation and suburbia in Northwest Europe: A comparative perspective on spatial trends and policy approaches. Progress in Planning. Advance online publication. https://doi.org/10.1016/j.progress. 2019.100462

Federal Ministry of Transport and Digital Infrastructure. (2020). Folgerungen für die zukünftige Verkehrspolitik nach den Erfahrungen und dem Umgang mit der Covid-19-Pandemie [Conclusions for future transport policy based on experiences of the Covid-19 pandemic]. Berlin: BMVI.

Feld, P., Schulten, A., Gerling, M., Simons, H., \& Wandzik, C. (2020). Immobilienwirtschaft in und nach der Corona-Krise (Herbstgutachten des Rates der Immobilienweisen) [The real estate industry in and after the Corona crisis (Autumn Report by the real estate expert panel)]. Berlin: ZIA Zentraler Immobilien Ausschuss e.V.

Fenton, P., \& Gustafsson, S. (2017). Moving from highlevel words to local action: Governance for urban sustainability in municipalities. Current Opinion in Environmental Sustainability, 26, 129-133.

Ferrão, P., \& Fernández, J. E. (2013). Sustainable urban metabolism. Cambridge, MA: The MIT Press.

Folke, C., Jansson, A., Rockström, J., Olsson, P., Carpenter, S. R., Chapin, F. S., . . . \& Westley, F. (2011). Recon- necting to the Biosphere. Ambio, 40. https://doi.org/ 10.1007/s13280-011-0184-y

Geissdoerfer, M., Savaget, P., Bocken, N. M., \& Hultink, E. J. (2017). The circular economy: A new sustainability paradigm? Journal of Cleaner Production, 143, 757-768.

German Advisory Council on Global Change. (2011). World in transition: A social contract for sustainability. Berlin: German Advisory Council on Global Change.

Ghisellini, P., Cialani, C., \& Ulgiati, S. (2016). A review on circular economy: The expected transition to a balanced interplay of environmental and economic systems. Journal of Cleaner Production, 114, 11-32.

Gutiérrez, A., Miravet, D., \& Domènech, A. (2020). Covid-19 and urban public transport services: Emerging challenges and research agenda. Cities \& Health. Advance online publication. https://doi.org/ 10.1080/23748834.2020.1804291

Haase, D., Kabisch, S., Haase, A., Andersson, E., Banzhaf, E., Baró, F., . . . \& Krellenberg, K. (2017). Greening cities: To be socially inclusive? About the alleged paradox of society and ecology in cities. Habitat International, 64, 41-48.

Hackmann, H., \& Lera St. Clair, A. (2012). Transformative cornerstones of social science research for global change. Paris: International Social Science Council.

Hakovirta, M., \& Denuwara, N. (2020). How Covid-19 redefines the concept of sustainability. Sustainability, 12(9). https://doi.org/10.3390/su12093727

Hamel, P., \& Keil, R. (2015). Suburban governance: A global view. Toronto: University of Toronto Press.

Hamidi, S., Sabouri, S., \& Ewing, R. (2020). Does density aggravate the Covid-19 pandemic? Journal of the American Planning Association, 86(4), 495-509.

High Level Political Forum on Sustainable Development. (2020). Building better after Covid-19 and acting where we will have the greatest impact on the SDGs: Bolstering local action to control the pandemic and accelerate implementation. New York, NY: United Nations. Retrieved from https://sustainable development.un.org/content/documents/ 26455HLPF_2020_Bolstering_local_action.pdf

Honey-Rosés, J., Anguelovski, I., Chireh, V., Daher, C., Konijnendijk van den Bosch, C., Litt, J., ... \& \& Nieuwenhuijsen, M. (2020). The impact of Covid-19 on public space: An early review of the emerging questions: Design, perceptions and inequities. Cities \& Health. Advance online publication. https://doi.org/ 10.1080/23748834.2020.1780074

Kabisch, S., Koch, F., Gawel, E., Haase, A., Knapp, S., Krellenberg, K., . . . \& Zehnsdorf, A. (Eds.). (2018). Urban transformations: Sustainable urban development through resource efficiency, quality of life and resilience (Vol. 10). Basel: Springer.

Kabisch, S., \& Kuhlicke, C. (2014). Urban transformations and the idea of resource efficiency, quality of life and resilience. Built Environment, 40(4), 475-485. 
Kanda, W., \& Kivimaa, P. (2020). What opportunities could the Covid-19 outbreak offer for sustainability transitions research on electricity and mobility? Energy Research \& Social Science, 68. https://doi.org/ 10.1016/j.erss.2020.101666

Klein, T., Köhler, D., \& Stein, T. (2020). Radverkehr im Ausnahmezustand: Mit Rückenwind aus der Krise [Cycling in a state of emergency: With tailwind out of the crisis] [Special issue]. Berichte: Das Magazin des DIFU. Retrieved from https://difu.de/sites/ default/files/media_files/2020-06/Difu-BerichteSonderheft_Juni-2020_Stadt-und-Krise_0.pdf

Kleinschroth, F., \& Kowarik, I. (2020). Covid-19 crisis demonstrates the urgent need for urban greenspaces. Frontiers in Ecology and the Environment, 18(6), 318-319.

Koch, F., Bilke, L., Helbig, C., \& Schlink, U. (2018). Compact or cool? The impact of brownfield redevelopment on inner-city micro climate. Sustainable Cities and Society, 38, 31-41.

Koch, F., Krellenberg, K., Reuter, K., Libbe, J., Schleicher, K., Krumme, K., . . . \& Kern, K. (2019). Wie lassen sich die Sustainable Development Goals umsetzen? Herausforderungen für Städte in Deutschland und die Rolle der Planung [How can the Sustainable Development Goals be implemented? Challenges for cities in Germany and the role of urban planning]. disP-The Planning Review, 55(4), 14-27.

Krellenberg, K., Koch, F., Schubert, S., \& Libbe, J. (2019). Einmal Transformation für alle, bitte! Kommunen, Stadtforschung, Forschungsförderung und die Umsetzung der SDGs [Transformation for all, please! Municipalities, urban studies, research funding and SDG implementation]. GAIA-Ecological Perspectives for Science and Society, 28(4), 337-341.

Krellenberg, K., Welz, J., Link, F., \& Barth, K. (2016). Urban vulnerability and the contribution of socioenvironmental fragmentation: Theoretical and methodological pathways. Progress in Human Geography, 41(4), 408-431.

Lai, K. Y., Webster, C., Kumari, S., \& Sarkar, C. (2020). The nature of cities and the Covid-19 pandemic. Current Opinion in Environmental Sustainability. Advance online publication. https://doi.org/10.1016/j.cosust. 2020.08.008

Leal Filho, W., Brandli, L. L., Lange Salvia, A., RaymanBacchus, L., \& Platje, J. (2020). Covid-19 and the UN sustainable development goals: Threat to solidarity or an opportunity? Sustainability, 12(13). https://doi. org/10.3390/su12135343

Lill, T. (2020, March 19). Gefährliche Verknappung [Dangerous shortage]. Der Spiegel. Retrieved from https://www.spiegel.de/auto/coronavirus-krisewarum-die-verknappung-des-oepnv-gefaehrlich-ista-019b9f07-ae67-47dc-8785-836035898348

Loorbach, D., \& Shiroyama, H. (2016). The challenge of sustainable urban development and transforming cities. In D. Loorbach, J. M. Wittmayer, H. Shiroyama,
J. Fujino, \& S. Mizuguchi (Eds.), Governance of urban sustainability transitions (pp. 3-12). Tokyo: Springer.

McCormick, K., Anderberg, S., Coenen, L., \& Neij, L. (2013). Advancing sustainable urban transformation. Journal of Cleaner Production, 50, 1-11.

Meerow, S., Newell, J. P., \& Stults, M. (2016). Defining urban resilience: A review. Landscape and Urban Planning, 147, 38-49.

Megahed, N. A., \& Ghoneim, E. M. (2020). Antivirusbuilt environment: Lessons learned from Covid-19 pandemic. Sustainable Cities and Society, 61. https:// doi.org/10.1016/j.scs.2020.102350

Messerli, P., Murniningtyas, E., Eloundou-Enyegue, P., Foli, E., Furman, E., Glassman, A., . . . van Ypersele, J.-P. (2019). Global sustainable development report 2019: The future is now. New York, NY: United Nations Press. Retrieved from https://sustainable development.un.org/content/documents/ 24797GSDR_report_2019.pdf

Neiderud, C. J. (2015). How urbanization affects the epidemiology of emerging infectious diseases. Infection Ecology \& Epidemiology, 5(1). https://doi.org/ 10.3402/iee.v5.27060

Newman, P. (2020). Covid-19, cities and climate: Historical precedents and potential transitions for the new economy. Urban Science, 4(3). https://doi.org/ 10.3390/urbansci4030032

Nightingale, A. J., Eriksen, S., Taylor, M., Forsyth, T., Pelling, M., Newsham, A., .. . \& Bezner Kerr, R. (2020). Beyond technical fixes: Climate solutions and the great derangement. Climate and Development, 12(4), 343-352.

Papon, K. (2020, October 28). Warum Schnäppchenjäger das Nachsehen haben [Why bargain hunters are left behind]. Frankfurter Allgemeine Zeitung. Retrieved from https://www.faz.net/aktuell/finanzen/meinefinanzen/mieten-und-wohnen/immobilienschnaeppchenjaeger-haben-das-nachsehen17024003.html

Patel, Z., Greyling, S., Simon, D., Arfvidsson, H., Moodley, N., Primo, N., \& Wright, C. (2017). Local responses to global sustainability agendas: Learning from experimenting with the urban sustainable development goal in Cape Town. Sustainability Science, 12(5), 785-797.

Pawlik, P. (2020, December 11). Corona und die Auswirkungen auf die Immobilienbranche [Corona and the impacts on the real estate industry]. Immobilien Aktuell Magazin. Retrieved from https://www. immobilien-aktuell-magazin.de/topics/covid-19corona-auswirkungen-auf-immobilienbranche

Pinheiro, M. D., \& Luís, N. C. (2020). Covid-19 could leverage a sustainable built environment. Sustainability, 12(14). https://doi.org/10.3390/su12145863

Ratho, A., \& Johns, P. (Eds.). (2020). Rethinking cities in a post-Covid-19 world. New Delhi: ORF and Global Policy Journal.

Revi, A., Satterthwaite, D., Aragón-Durand, F., Corfee- 
Morlot, J., Kiunsi, R. B. R., Pelling, M., . . . \& Sverdlik, A. (2014). Towards transformative adaptation in cities: The IPCC's fifth assessment. Environment and Urbanization, 26(1), 11-28.

Romero-Lankao, P., McPhearson, T., \& Davidson, D. (2017). The food-energy-water nexus and urban complexity. Nature Climate Change, 7(4), 233-235.

Romero-Lankao, P., \& Qin, H. (2011). Conceptualizing urban vulnerability to global climate and environmental change. Current Opinion in Environmental Sustainability, 3(3), 113-120.

Schneider, S. (2020). Urbane versus rurale Qualitäten: Stadt-Land-Verhältnis nach dem Lockdown [Urban versus rural qualities: Urban-rural relationship after the lockdown] [Special issue]. Berichte: Das Magazin des Difu. Retrieved from https://difu.de/sites/ default/files/media_files/2020-06/Difu-BerichteSonderheft_Juni-2020_Stadt-und-Krise_0.pdf

Sharifi, A., \& Khavarian-Garmsir, A. R. (2020). The Covid-19 pandemic: Impacts on cities and major lessons for urban planning, design, and management. Science of The Total Environment, 749. https://doi. org/10.1016/j.scitotenv.2020.142391

Simon, D., Arfvidsson, H., Anand, G., Bazaz, A., Fenna, G., Foster, K., . . \& \& Wright, C. (2016). Developing and testing the Urban Sustainable Development Goal's targets and indicators: A five-city study. Environment and Urbanization, 28(1), 49-63.

Slater, J., Masih, N., \& Dutta, T. (2020, November 15). India's capital is battling a surge in coronavirus cases just as pollution levels spike. The Washington Post. Retrieved from https://www.washingtonpost.com/ world/asia_pacific/india-delhi-coronaviruspollution/2020/11/14/2e8745ca-2479-11eb-9c4a0dc6242c4814_story.html

Sofo, A., \& Sofo, A. (2020). Converting home spaces into food gardens at the time of Covid-19 quarantine: All the benefits of plants in this difficult and unprecedented period. Human Ecology, 48(2), 1-9.

Solecki, W., Seto, K. C., \& Marcotullio, P. J. (2013). It's time for an urbanization science. Environment: Science and Policy for Sustainable Development, 55(1), 12-17.

Spiegel Mobilität. (2020, June 12). Unter den oberen Zehntausend fährt so gut wie niemand mehr öffentlich [Hardly anyone in the top ten thousand drives publicly]. Der Spiegel. Retrieved from https:// www.spiegel.de/auto/corona-krise-beim-oepnvobere-zehntausend-meiden-busse-und-bahnen-a2a3cb014-54c0-4da3-92ed-f3d891a17388

Stadtlücken. (2020). Kooperativer Stadtraum: Österreichischer Platz [Cooperative urban space: Österre- ichischer Platz]. Stadtlücken. Retrieved from https:// www.oe-platz.de/information

Statistisches Bundesamt. (2020). Flächennutzung Flächenindikator: Anstieg der Siedlungs- und Verkehrsfläche in ha/Tag [Land use area indicator: Increase in settlement and traffic area in ha/day]. Statistisches Bundesamt. Retrieved from https:// www.destatis.de/DE/Themen/BranchenUnternehmen/Landwirtschaft-ForstwirtschaftFischerei/Flaechennutzung/Tabellen/anstiegsuv.html

Troy, A. (2012). The very hungry city: Urban energy efficiency and the economic fate of cities. New Haven, CT and London: Yale University Press.

Tukiainen, T., Leminen, S., \& Westerlund, M. (2015). Cities as collaborative innovation platforms. Technology Innovation Management Review, 5(10), 16-23.

Twigg, J., Lovell, E., Schofield, H., Morel, L. M., Flinn, B., Sargeant, S., . . . \& Rossetto, T. (2017). Self-recovery from disasters (ODI Working Paper No. 523). London: Overseas Development Institute.

UN. (2015). Transforming our world: The 2030 Agenda for Sustainable Development: Resolution adopted by the General Assembly on 25 September 2015, $A / R E S / 70 / 1$. New York, NY: United Nations.

UNESCO. (2020). Urban solutions: Learning from cities' responses to Covid-19 (online meeting report). Paris: UNESCO. Retrieved from https://en. unesco.org/urban-solutions-Learning-from-citiesresponses-to-Covid-1919

UN Habitat. (2015). Climate change strategy (2014-2019). Nairobi: United Nations Human Settlements Programme.

Venter, Z., Barton, D., Gundersen, V., Figari, H., \& Nowell, M. (2020). Urban nature in a time of crisis: Recreational use of green space increases during the Covid-19 outbreak in Oslo, Norway. Environmental Research Letters, 15(10). https://doi.org/10.1002/ ael2.20033

Weichselgartner, J., \& Kelman, I. (2015). Geographies of resilience: Challenges and opportunities of a descriptive concept. Progress in Human Geography, 39(3), 249-267.

Węziak-Białowolska, D. (2016). Quality of life in cities: Empirical evidence in comparative European perspective. Cities, 58, 87-96.

Xiong, J., Lipsitz, O., Nasri, F., Lui, L. M., Gill, H., Phan, L., ... \& McIntyre, R. S. (2020). Impact of Covid-19 pandemic on mental health in the general population: $A$ systematic review. Journal of Affective Disorders, 277, 55-64. 


\section{About the Authors}

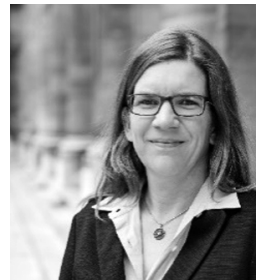

Kerstin Krellenberg is Professor of Urban Studies at University of Vienna, Austria. She holds a Diploma in Environmental Studies and a PhD and Habilitation in Geography. Her publication record is on Urban Sustainability Transformations, SDG Implementation, Urban Ecosystem Services, Urban Vulnerability, and Adaptation. Global environmental change and digital change as well as the impacts on, and the challenges and opportunities for cities are central to her work on human-environment-technology interactions. She aims at developing integrative approaches through inter- and transdisciplinary cooperation.

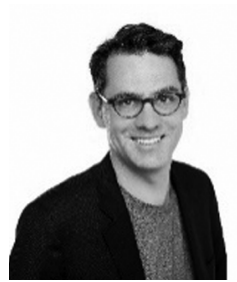

Florian Koch is a Professor of Real Estate Management, Urban Development and Smart Cities at the University of Applied Sciences in Berlin, Germany (HTW Berlin). He is trained as a Spatial Planner and Social Scientist, and has authored several books and articles on the localization of the Sustainable Development Goals, urban transformations, multi-level governance, and sustainable and smart urban development. 